\title{
Bond Strength of Three Dental Porcelains to Ni-Cr and Co-Cr-Ti Alloys
}

\author{
Alfredo Julio FERNANDES NETO ${ }^{1}$ \\ Heitor PANZERI ${ }^{2}$ \\ Flavio Domingues NEVES ${ }^{1}$ \\ Ricardo Alves do PRADO ${ }^{1}$ \\ Gustavo MENDONÇA ${ }^{1}$ \\ ${ }^{1}$ Department of Occlusion, Fixed Prosthesis and Dental Materials, Faculty of Dentistry, \\ Federal University of Uberlândia, Uberlândia, MG, Brazil \\ ${ }^{2}$ Department of Dental Materials and Prosthodontics, Faculty of Dentistry of Ribeirão Preto, \\ University of São Paulo, Ribeirão Preto, SP, Brazil
}

\begin{abstract}
Ceramometal bond strength has played an important role for the replacement of gold alloys by nickel-chromium alloys in dentistry. This study evaluated the metal/porcelain bond strength of three ceramic systems (Vita VMK 88, Williams and Duceram) associated with three nickel-chromium alloys (Durabond, Lite Cast B and Resistal P) and one experimental cobalt-chromium-titanium alloy. Thirty cast cylinder specimens ( $15 \mathrm{~mm}$ in height; $6 \mathrm{~mm}$ in diameter) were obtained for each alloy, in away that 10 specimens of each alloy were tested with each porcelain. Bond strength was measured with an Emic screw-driven mechanical testing machine by applying parallel shear forces to the specimens until fracture. Kruskal-Wallis and Mann-Whitney U tests were used for statistical analysis of the alloy/ceramic combinations ( $p<0.05)$. Resistal P/Duceram had significantly higher bond strength $(44.38 \pm 9.12 \mathrm{MPa})(\mathrm{p}<0.05)$ than the other combinations, except for Co-Cr-Ti alloy/Vita VMK 88 (38.41 $\pm 12.64 \mathrm{MPa})$. The association of the experimental Co-Cr-Ti alloy with Williams porcelain had significantly higher bond strength $(28.20 \pm 3.86 \mathrm{MPa})$ than the combination of other alloys with the same porcelain $(\mathrm{p}<0.05)$. Based of these results and within the limitations of an in vitro study, it may be concluded that the bond strength of the three ceramic systems to the $\mathrm{Ni}-\mathrm{Cr}$ and $\mathrm{Co}-\mathrm{Cr}$-Ti alloys varied significantly, indicating that metal/ceramic compatibility was very important to the bond strength.
\end{abstract}

Key Words: metal ceramic alloys, dental porcelain, shear bond strength.

\section{INTRODUCTION}

Alternative alloys for fabrication of ceramometal restorations were introduced in the 1960s but became more popular after the cost of gold alloys increased (14). The advantages of base metal alloys over gold alloys have been reported $(1,2)$ and their properties have been compared in terms of creep (1), metal-porcelain bonding (5-7) and composition (8). The mechanical properties of base metal alloys allow fabricating restorations with greater rigidity and lesser thickness. Their disadvantages include potential biologic hazards, difficult handling and uncontrolled chromium oxide formation $(9,10)$.
Nickel-chromium (Ni-Cr) and cobalt-chromium (Co-Cr) alloys are the most widely used when cost and rigidity are considered. Nevertheless, these alloys are not universally accepted for casting because they contain beryllium (Be) and other substances that can be harmful (9). In addition, due to their hardness, $\mathrm{Ni}-\mathrm{Cr}$ and $\mathrm{Co}-\mathrm{Cr}$ alloys are difficult to deal with in the laboratory, rendering necessary accurate casting and preparation procedures prior to firing the porcelain (10).

Studies have attempted to explain the nature of the composition that leads to adhesion at metal/ceramic interface $(5,8,10,11)$. The success of porcelain-fusedto-alloy restorations depends on an optimal bond between

Correspondence: Prof. Dr. Alfredo Julio Fernandes Neto, Área de Oclusão, Prótese Fixa e Materiais Odontológicos, Faculdade de Odontologia, Universidade Federal de Uberlândia, Av. Pará, s/n, Bloco 2B, Sala 2B01, Campus Umuarama, 38400-902 Uberlândia, MG, Brasil. Tel/Fax: +55-16-34-3218-2222. e-mail: alfredon@ufu.br 
ceramic and metal substructure (8). The chemical compatibility between metal and porcelain allows the restoration to wihtstand thermal stresses and mechanical forces. This includes a fusing temperature of porcelain that not only does not cause distortion of the metal substructure and contraction of the porcelain, but also can be resisted by the metal (12). Therefore, many studies have been carried out to investigate the metal/ ceramic bonding (2-4,12-16). If planning to use base metal alloys for fabrication of ceramometal restorations, dental technicians and dentists must select the materials taking into account the quality of the adhesion between the alloy and the porcelain system (17-19).

The purpose of this study was to evaluate the shear bond strength of three ceramic systems to three $\mathrm{Ni}-\mathrm{Cr}$ alloys and an experimental $\mathrm{Co}-\mathrm{Cr}-\mathrm{Ti}$ alloy.

\section{MATERIAL AND METHODS}

Three ceramic systems [Durabond (Comercial Odonto Import Ltd., São Paulo, SP, Brazil); Lite Cast B (Williams Dental Co., New York, NY, USA); Resistal P (Degussa, Frankfurt, Germany)] were bonded to three Ni-Cr alloys [Vita VMK 88 (Vita Zahnfabrick H. Rauter GmbH \& Co., Bad Säckingen, Germany); Williams (Williams Dental Co.); Duceram (Degussa)] and an experimental Co-Cr-Ti alloy (developed at the Faculty of Dentistry of Ribeirão Preto, FORP/USP, Brazil). The composition of the metal alloys is shown in Table 1.

The metal/ceramic specimens were fabricated and tested using a stainless steel mold modified from Shell and Nielsen $(7,20)$, that consisted of two parts: a lower base, with a vertical cylindrical perforation (15 $\mathrm{mm}$ in height; $6 \mathrm{~mm}$ in diameter), and an upper, semicircular, removable portion with a central perforation (3 $\mathrm{mm}$ high; $8.4 \mathrm{~mm}$ in diameter) that fit perfectly into the upper surface of the lower base (Fig. 1).

Thirty standard wax cylinders (15 $\mathrm{mm}$ in height; $6 \mathrm{~mm}$ in diameter) were cast from each alloy. A high-

Table 1. Composition (\%) of the Ni-Cr and Co-Cr-Ti alloys.

\begin{tabular}{lrccccccc}
\hline Alloy & $\mathrm{Ni}$ & $\mathrm{Co}$ & $\mathrm{Cr}$ & $\mathrm{Mo}$ & $\mathrm{Ti}$ & $\mathrm{Be}$ & $\mathrm{Mg}$ & $\mathrm{FeSiC}$ \\
\hline Durabond & 62.5 & - & 19.7 & - & - & - & - & - \\
Litecast B & 78.0 & - & 13.0 & 4.0 & - & 1.7 & - & - \\
Resistal P & 61.0 & - & 21.5 & 9.0 & - & - & - & - \\
Experimental & 5.0 & 54.0 & 15.0 & 3.0 & 10 & - & 1.0 & 1.0 \\
\hline
\end{tabular}

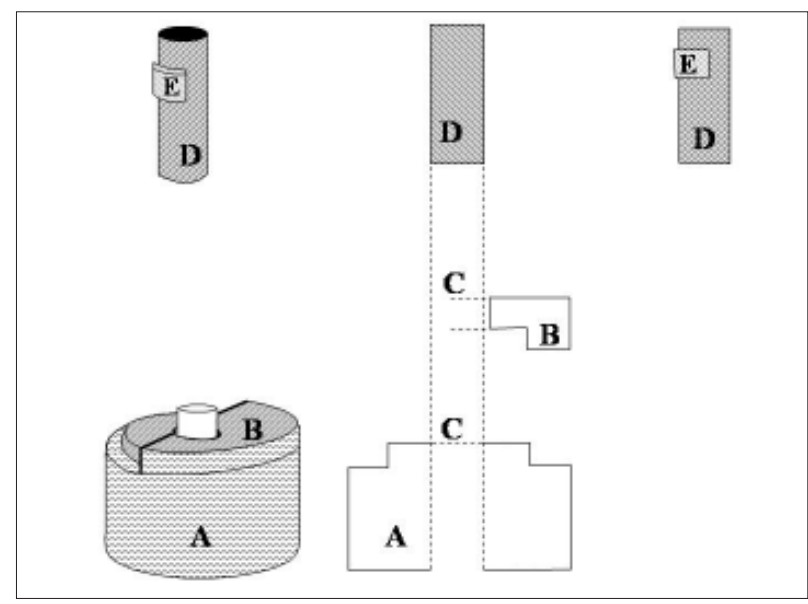

Figure 1. Schematic drawing of the stainless steel mold used for specimen preparation, porcelain application and shear strength testing. A: Lower portion. B: Upper portion. C: Central cylindrical perforation. D: Tested Specimen. E: Porcelain layer.

temperature phosphate-bonded investment (Termocast, Polidental Ltd., São Paulo, SP, Brazil) was used and, 45 min after investment (setting at room temperature), the rings were burned-out according to the manufacturer's instructions. Alloys were melted in individual crucibles with a multiorifice gas-oxygen torch and cast in a broken-arm centrifugal casting machine (Kerr/Sybron, Romulus, MI, USA), with its arm set at four turns. After casting, each ring was bench-cooled and the casting pieces were divested. The specimens were cleaned with $50-\mu \mathrm{m}$ glass beads in a non-recycling machine (Trijato, Labordental Ltd., São Paulo, SP, Brazil) (Fig. 2).

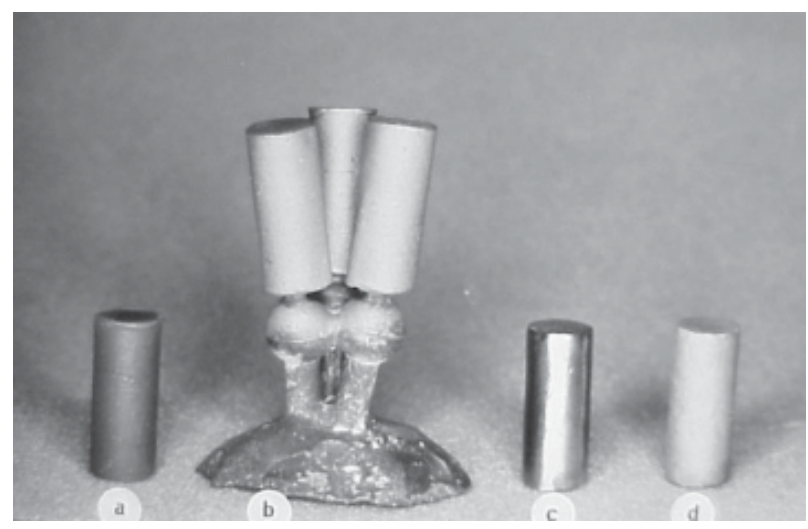

Figure 2. Sequence of specimen preparation before porcelain build-up. A: Wax pattern. B: Casting. C: After finishing with aluminum-oxide burs. D. After aluminum-oxide jet finishing. 
The cylindrical specimens were metallographically polished on both sides to make them parallel to each other using 400- and 600-grit silicon carbide papers (Arotec, Cotia, SP, Brazil). The rounded surface of the cylinders was polished with an aluminum oxide stone to fit in the mold. The area for porcelain bonding was air abraded with $50-\mu \mathrm{m}$ aluminum oxide to eliminate contamination (Trijato; Labordental Ltd.) (Fig. 2).

The porcelain was built-up according to the manufacturer's instructions for temperature and atmospheric conditions (Table 2). The porcelain was applied on a semi-circular area on the upper portion of the mold. The cylindrical specimens were positioned in the lower half of the mold, with approximately half of its height above that. As the circular upper portion of the mold presents a hole with $8.4 \mathrm{~mm}$ in diameter and 3.0 $\mathrm{mm}$ in height, it provided a porcelain layer with similar dimensions for all specimens $(1.2 \times 3.0 \mathrm{~mm}$, with an area of $3.6 \mathrm{~mm}^{2}$ ). Two layers of opaque porcelain and two of body porcelain were applied (Fig. 3).

Bond strength testing was carried out by applying parallel shear forces to the specimens while they were under a constant strain within the stainless steel mold. The lower part of the mold was placed on a screwdriven mechanical testing machine (model MEM 2000, Emic Equipment and Test Systems Ltd., São José de Pinhais, PR, Brazil). The shear forces were generated at the metal-porcelain interface at a crosshead speed of 0.5 $\mathrm{mm} / \mathrm{min}$ until failure occurred. Compressive force was applied to the top surface of the alloys and stress was produced at the opaque/metal interface, which was supported on the surface of the mold. This compression force generated a resistance force to shear tension. Shear bond strength was calculated in MPa.

Levine statistics for homogeneity of variances was used to determine whether parametric statistical tests were suitable for comparison of the collected data. However, because the variances were not homogeneous, bond strength means were ranked and Kruskal-Wallis and Mann-Whitney U nonparametric tests were applied to the ranks at $5 \%$ significance level. systems and alloys.

\section{RESULTS}

Kruskal-Wallis and Mann-Whitney U tests showed statistically significant interaction between metals and ceramics $(\mathrm{p}<0.05)($ Table 3$)$. The Duceram system fused to Resistal $P$ had significantly higher bond strengths than the other combinations $(\mathrm{p}<0.05)$, except for Vita VMK 88 fused to the Co-Cr-Ti alloy. The Williams system fused to the Co-Cr-Ti alloy had significantly

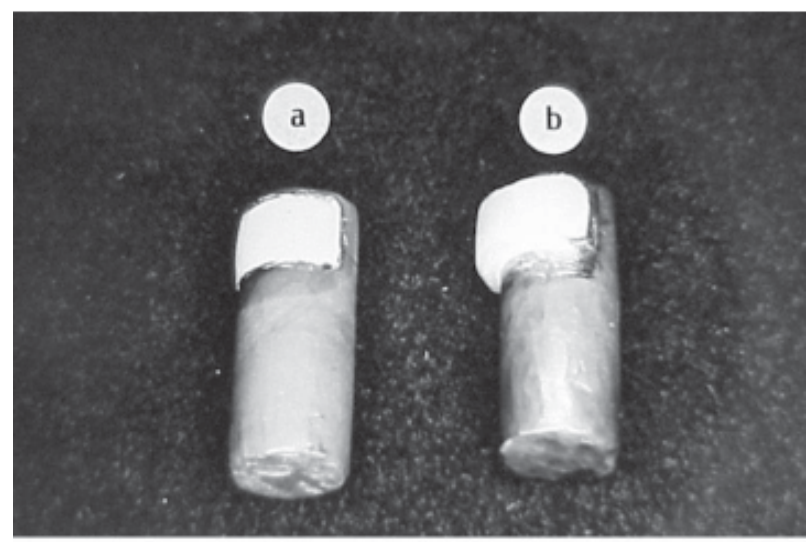

Figure 3. Specimens with the opaque (A) and porcelain body after firing (B).

Table 2. Ceramic firing cycles.

\begin{tabular}{|c|c|c|c|c|c|c|}
\hline \multirow[t]{3}{*}{ Porcelain } & \multicolumn{3}{|c|}{ Opaque bakes } & \multicolumn{3}{|c|}{ Body bakes } \\
\hline & \multicolumn{3}{|c|}{ Temperature } & \multicolumn{3}{|c|}{ Temperature } \\
\hline & Initial & - & Final & Initial & - & Final \\
\hline Vita VMK 88 & $750^{\circ} \mathrm{C}$ & - & $980^{\circ} \mathrm{C}$ & $750^{\circ} \mathrm{C}$ & - & $960^{\circ} \mathrm{C}$ \\
\hline Williams & $540^{\circ} \mathrm{C}$ & - & $980^{\circ} \mathrm{C}$ & $540^{\circ} \mathrm{C}$ & - & $960^{\circ} \mathrm{C}$ \\
\hline Duceram & $650^{\circ} \mathrm{C}$ & - & $990^{\circ} \mathrm{C}$ & $650^{\circ} \mathrm{C}$ & - & $940^{\circ} \mathrm{C}$ \\
\hline
\end{tabular}

Table 3. Shear bond strength means (MPa) and standard deviation of the combinations of ceramic

\begin{tabular}{lcccc}
\hline Porcelain & \multicolumn{5}{c}{ Alloy } \\
& \multicolumn{5}{c}{ Durabond } & Lite Cast B & Resistal P & Experimental \\
\cline { 2 - 5 } & & & \\
\hline Vita VMK 88 & $27.93 \pm 5.66 \mathrm{~cd}$ & $27.14 \pm 4.95 \mathrm{cde}$ & $32.95 \pm 6.00 \mathrm{bc}$ & $38.41 \pm 12.64 \mathrm{ab}$ \\
Williams & $22.54 \pm 8.46 \mathrm{ef}$ & $23.69 \pm 5.22 \mathrm{ef}$ & $22.08 \pm 3.23 \mathrm{f}$ & $28.20 \pm 3.86 \mathrm{~cd}$ \\
Duceram & $35.11 \pm 8.97 \mathrm{bc}$ & $30.48 \pm 5.97 \mathrm{bc}$ & $44.38 \pm 9.12 \mathrm{a}$ & $36.51 \pm 16.75 \mathrm{bc}$ \\
\hline
\end{tabular}

*Different letters indicate statistically significant difference $(\mathrm{p}<0.05)$. 
higher bond strength $(p<0.05)$ than the other combinations of the same porcelain with other alloys.

\section{DISCUSSION}

This study evaluated the bonding characteristics of three commercially available porcelains fused to three $\mathrm{Ni}-\mathrm{Cr}$ alloys and one experimental Co-Cr-Ti alloy, using a modified rectangular parallel shear test (20), which determined the shear strength required to break the ceramometal bonding of a ceramic ring constructed around cylinder-shaped metal rods. This test was based on the test proposed by Shell and Nielsen (7), which avoids great stress concentration because of the semicircumferential configuration of the porcelain around the cylindrical metal rods. However, unknown residual interface stresses may occur because of small differences in the thermal contraction coefficients of the porcelain and metal $(4,15)$. The shear stress along the interface is maximal at the point closest to the applied force and is minimal at the bottom of the porcelain, rather than a uniform shear stress that can increase the possibility of porcelain fracture (20). If only the porcelain fractured, the force measured would correspond to the porcelain resistance and not to the resistance of metal/porcelain interface. However, it did not occur in this study.

The tested $\mathrm{Ni}-\mathrm{Cr}$ alloys and porcelains are frequently used by dentists in Brazil. The experimental Co-Cr-Ti alloy, developed at the Faculty of Dentistry of Ribeirão Preto (University of São Paulo, Ribeirão Preto, SP, Brazil), presents better corrosion strength because of the presence of titanium. However, further research should be carried out to provide more information about other properties of this alloy.

The bond strength values obtained in this study for the $\mathrm{Ni}-\mathrm{Cr}$ alloys are consistent with those of previous studies $(8,19)$. Other investigations have also reported the existence of significant differences among commercially available brands of Ni-Cralloys $(13,14,16-$ 18). Comparison to other studies may be misleading because of variations in mechanical properties of the alloys. It is also important to point out that the framework strength does not depend exclusively on the alloy used, but also on its design $(16,17)$. Sharp and much defined shapes often have very low resistance to fracture (16). Therefore, alloys to be use in ceramometal restorations cannot be chosen by clinicians based exclusively on material bond strength.
The findings of this study showed that there were significant differences among the tested combinations. It is important to point out that little research has been done with Duceram and Williams systems and further investigation is needed. On the other hand, the results of this study are in agreement with those of other works with Vita VMK system $(8,18,19)$. These outcomes may be due to the expansion curves and residual contraction of this system because, although its maximum expansion is similar to that of other ceramic systems, the residual contraction of Vita VMK after cooling is quite significant (8).

Hammad et al. (14) reported lower bond strength for Vita VMK 88/Durabond alloy, when the alloy was submitted to previous oxidation. Moffa et al. (8), evaluating the shear bond strength of noble and base metal alloys, reported that the latter did not differ statistically and the values obtained were significantly higher than that of the control gold-based alloy. Lubovich and Goodkind (18) found bond strengths lower or higher than those of traditional gold-based alloys in comparison to three base metal alloys. These studies indicate that great variations can occur regarding the bond strengths of base metal alloys. This can be related to divergences in methodologies, metal casting and preparation or differences in the dental porcelains used. On the other hand, the excellent performance of the experimental alloy in combination with the Vita VMK 88 and Duceram systems showed that alloys with titanium are promising for ceramometal restorations (12).

Although these data can be helpful for selection of the most suitable materials for clinical use, it is important to highlight that the continuous development of new metal alloys and ceramic systems implicates in constant research to assess the compatibility of the metal-porcelain combinations. This means that the metal alloys and ceramic systems tested in this study may present higher shear strength if combined with other materials or techniques specifically developed for each type of alloy or ceramic system available. Longitudinal clinical trials are also required to investigate the behavior of these materials in metal-ceramic restorations under clinical conditions

\section{RESUMO}

A resistência da união metal/porcelana tem um importante papel na subistituição das ligas de ouro por ligas à base de níquel-cromo 
na Odontologia. Este estudo avaliou a resistência da união metal/ porcelana de três sistemas cerâmicos (Vita VMK 88, Williams e Duceram) em combinação com três ligas metálicas à base de níquel-cromo (Durabond, Lite Cast B e Resistal P) e uma liga experimental à base de cobalto-cromo-titânio. Trinta corpos-deprova cilíndricos ( $15 \mathrm{~mm}$ de altura; $6 \mathrm{~mm}$ de diâmetro) foram obtidos para cada liga, sendo 10 corpos-de-prova de cada liga testados com cada uma das porcelanas. A resistência de união foi calculada utilizando uma máquina EMIC aplicando uma força de cisalhamento paralela ao corpo-de-prova até a fratura. Os testes de Kruskal-Wallis e U de Mann-Whitney foram usados para a análise estatistica das interações metal/porcelana $(\mathrm{p}<0,05)$. A combinação Duceram/Resistal $\mathrm{P}$ apresentou resistência de união significantemente maior $(44,38 \pm 9,12 \mathrm{MPa})(\mathrm{p}<0,05)$ que as outras combinações, exceto a associaçãoVita VMK 88/liga experimental Co-Cr-Ti $(38,41 \pm 12,64 \mathrm{MPa})$. A combinção da liga de Co-Cr-Ti com o sistema cerâmico Williams teve resistência ao cisalhamento significantemente maior que a combinação das outras ligas com a mesma porcelana $(28,20 \pm 3,86 \mathrm{MPa})(\mathrm{p}<0,05)$. Com base nestes resultados e dentro das limitações de um estudo in vitro, pode-se concluir que a resistência da união metal/porcelana dos três sistemas cerâmicos testados às ligas de $\mathrm{Ni}$-Cr e Co-Cr-Ti variaram significativamente, mostrando que a compatibilidade metal/ porcelana foi muito importante para esta união.

\section{REFERENCES}

1. Anusavice KJ, Shen C, Hashinger D, Twiggs SW. Interactive effect of stress and temperature on creep of PFM alloys. J Dent Res 1985;64:1094-1099.

2. Papazoglou E, Brantley WA, Carr AB, Johnston WM Porcelain adherence to high-palladium alloys. J Prosthet Dent 1993;70:386-394.

3. Papazoglou E, Brantley WA. Porcelain adherence vs force to failure for palladium-gallium alloys: A critique of metalceramic bond testing. Dent Mater 1998;14:112-119.

4. Papazoglou E, Brantley WA, Johnston WM, Carr AB. Effects of dental laboratory processing variables and in vitro testing medium on the porcelain adherence of high-paladium casting alloys. J Prosthet Dent 1998;79:514-519.

5. Anusavice KJ, Ringle RD, Fairhurst CW. Bonding mechanism evidence in a ceramic nonprecious alloy system. J Biomed
Mater Res 1977;11:701-709.

6. Anusavice KJ, Ringle RD, Fairhurst CW. Adherence controlling elements in ceramic-metal systems. II. Nonprecious alloys. J Dent Res 1977;56:1053-1061.

7. Shell JS, Nielsen JP. Study of the bond between gold alloys and porcelain. J Dent Res 1962;44:1424-1437.

8. Nally JN. Chemico-physical analysis and mechanical test of the ceramo-metallic complex. Int Dent J 1968;18:309-325.

9. Bezzon OL, Mattos MGC, Ribeiro RF, Rollo JMDA. Effect of beryllium on the castability and resistence of ceramometal bonds in nickel-chromium alloys. J Prosthet Dent 1998;80:570-574.

10. Bezzon OL, Ribeiro RF, Rollo JMDA, Crosara S. Castability and resistence of ceramometal bonding in $\mathrm{Ni}-\mathrm{Cr}$ and $\mathrm{Ni}-\mathrm{Cr}-\mathrm{Be}$ alloys. J Prosthet Dent 2001;85:299-304.

11. Lacy AM. The chemical nature of dental porcelain. Dent Clin N Amer 1977;21:661-667.

12. Yilmaz H, Dinçer C. Comparison of the bond compatibility of titanium and an Ni-Cr alloy to dental porcelain. J Dent 1999;27:215-222.

13. Prado RA, Panzeri H, Fernandes Neto AJ, Neves FD, Silva MR, Mendonça G. Shear bond strength of dental porcelains to nickel-chromium alloys. Braz Dent J 2005;16:202-206.

14. Hammad IA, Goodkind RJ, Gerberich WW. A shear test for bond strength of ceramometals. J Prosthet Dent 1987;58:431-437.

15. Schaffer SP. An approach to determining the bond strength of ceramometal system. J Prosthet Dent 1982;48:282-284.

16. Warphea WS, Goodkind RJ. Design and technique variables affecting fracture resistance of metal-ceramic restorations. J Prosthet Dent 1976;35:291-298.

17. Daftary F, Donovan T. Effect of four pretreatment techniques on porcelain-to-metal bond strength. J Prosthet Dent 1986;56:535-539.

18. Lubovich RP, Goodkind RJ. Bond strength studies of precious, semiprecious, and nonprecious ceramic-metal alloys with two porcelains. J Prosthet Dent 1977;37:288-299.

19. Lund PS, Goodkind RJ, Swanson S. Residual stress in several ceramometal systems. J Prosthet Dent 1989;62:278-283.

20. Anusavise KJ, Dehoff PH, Fairhurst CW. Comparative evaluation of ceramic-metal bond tests using finite element stress analysis. J Dent Res 1980;59:608-613.

Accepted June 4, 2005 